\title{
13
}

\section{Phase 3: The Emergence of Ditches}

\author{
Tim Denham, Jack Golson and Philip Hughes
}

Ditches and associated artefacts ranging in age from roughly 4000-2000 years old have been documented at Kuk and several other wetlands in the highland interior of New Guinea (Fig. 13.1 and Table 13.1). Ditches and ditch networks have been mapped and investigated in greatest detail at Kuk, while more limited excavation, recording and dating have occurred elsewhere: in the upper Wahgi Valley at the Manton site on Warrawau Plantation; in the middle Wahgi Valley at Kana; at Tambul in the upper Kaugel Valley; and at Haeapugua in the Tari Basin (see Table 13.1). The archaeological remains at Kuk have guided the interpretation of finds at other sites.
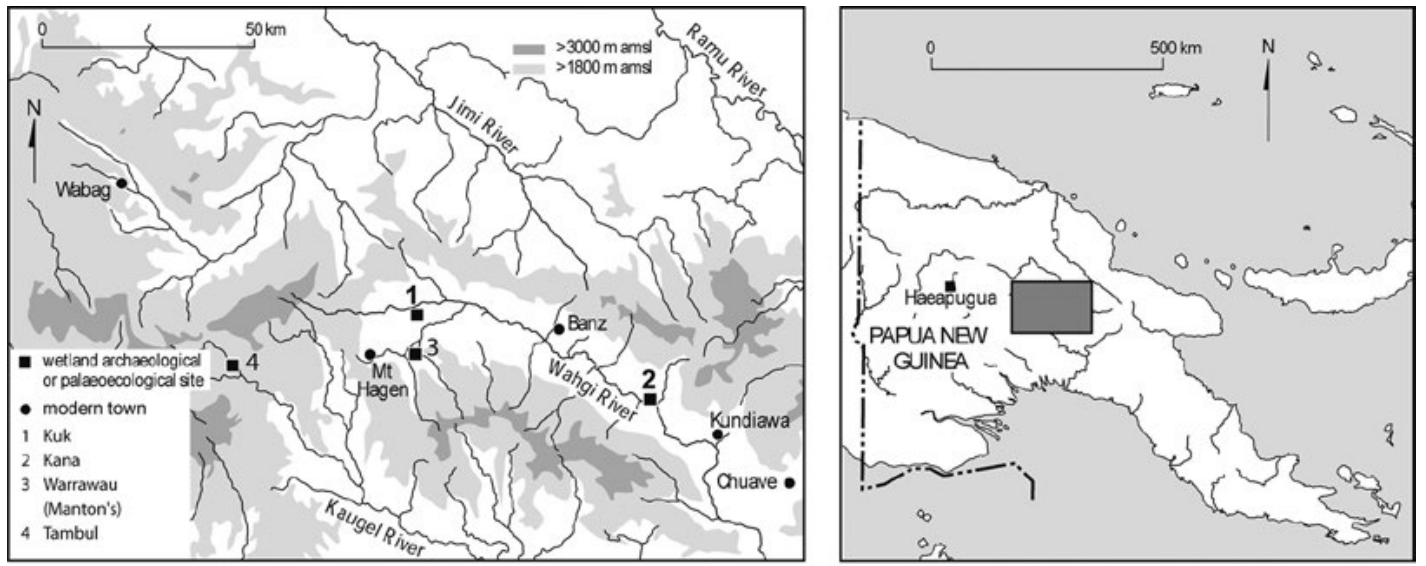

Figure 13.1 The location of archaeological sites with evidence of drainage networks contemporary with Phase 3 at Kuk.

Source: Denham (2005: Fig. 1), reproduced with permission.

\section{The earliest ditch networks at Kuk}

Ditch networks at Kuk were traced in numerous excavation trenches dug across the wetland in 1974-77 and 1998-99 (Fig. 13.2). Phase 3 at Kuk consists of at least three palaeochannels associated with networks of linear ditches, with few artefacts recovered during the limited excavation of ditch fills. Only in 1998 and 1999 were ditches systematically excavated to investigate fills, to collect associated artefacts and to undertake sampling for palaeoenvironmental reconstruction. 

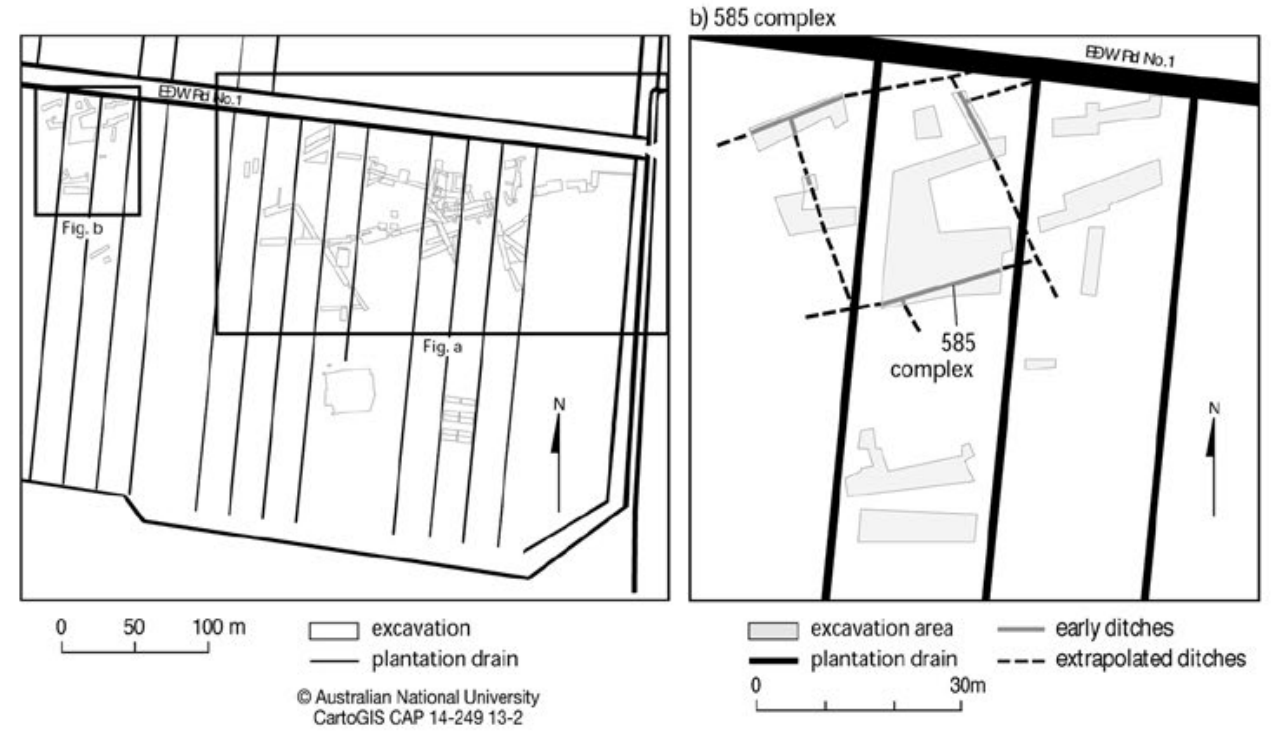

a) $107,203,353$ and $350 / 393$ complexes

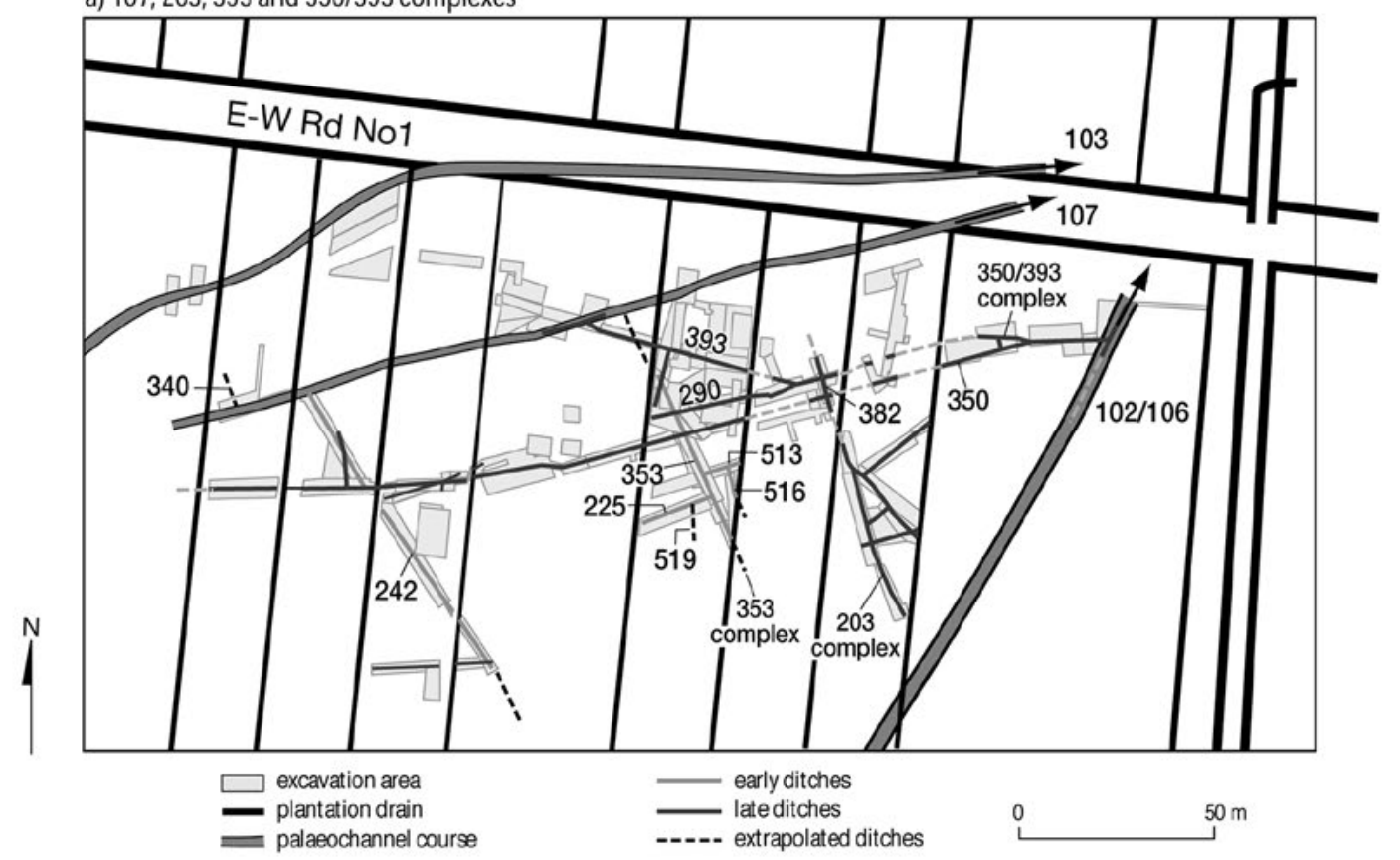

Figure 13.2 Plans showing the nature and extent of early and late Phase 3 networks.

The networks are reconstructed from exposures in excavation trenches and station drains in two areas at Kuk: a) blocks A11 and $\mathrm{A} 12$; and b) block A10.

Source: Denham, Golson and Hughes (2004: Fig. 16), reproduced with permission.

Phase 3 ditches are not visible as surface depressions or vegetation marks on aerial photographs because any trace is masked by more recent deposition of sediment in the swamp. Very few of the shallower features, potentially associated with former cultivation on surfaces between ditches, were found and any that existed have been reworked by later gardening and soil formation. 
a) ditch 353

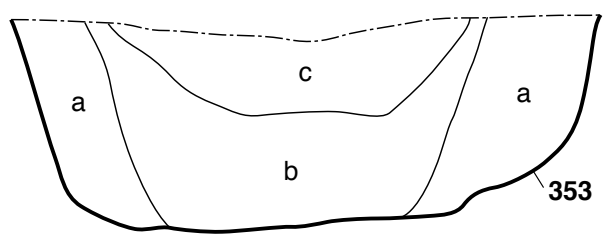

b) ditch 203

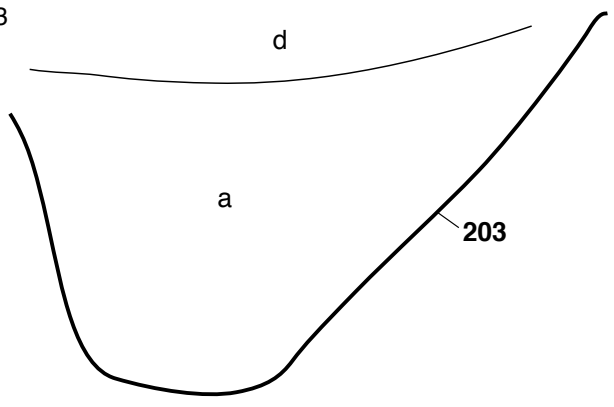

c) ditch 350
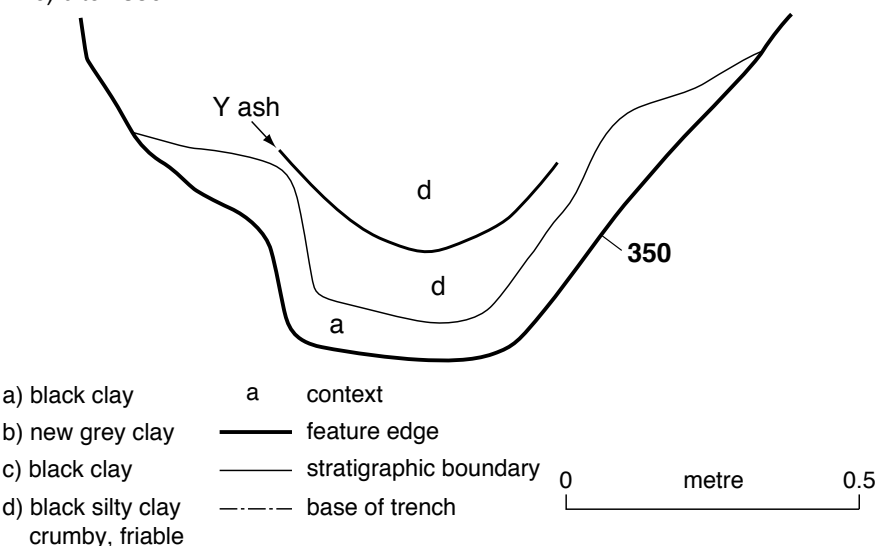

Figure 13.3 Schematic representation of stratigraphic criteria used to group Phase 3 ditches into subphases.

a) early, b) mid to late and c) late.

Source: Denham, Golson and Hughes (2004: Fig. 17), reproduced with permission.

In stratigraphic terms, Phase 3 postdates deposition of $\operatorname{Kim}(\mathrm{R})$ tephra and predates deposition of Mun (Niupela or NP) and Baglaga (Y) tephras (see Fig. 6.10). Phase 3 ditches contain a basal fill of massive black clay that is indistinguishable from the main black clay stratigraphic unit. Most ditches lack archaeological associations with features or deposits of known age. Consequently, fill stratigraphy has been used to group Phase 3 ditches into the following subphases (Fig. 13.3a-c):

a. Early subphase ditches contained a three-part fill sequence of basal black clay, middle grey clay (referred to in the field as 'new grey clay', probably derived from erosion of the small tephra-covered hills of the southern catchment) and upper black clay;

b. Mid to late subphase ditches contained a basal black clay fill with a level or slightly dipping lens of Baglaga ( $\mathrm{Y}$ ) ash above; and

c. Late subphase ditches contained a basal black clay fill with a slight to moderately dipping lens of Baglaga $(\mathrm{Y})$ ash above.

These stratigraphic criteria evolved during the course of the project and served as guides to the age of an individual ditch. 
Phase 3 ditch networks lack the extensive grid-like patterns of the more recent drainage systems of Phases 4-6 (see Chapters 14-16) and some present-day ditch networks in the highlands (see Chapter 5). They display some rectilinear components (i.e. ditches form rectangular patterns in plan, Fig. 13.4a), whereas other components are dendritic (i.e. ditches branch at acute angles, Fig. 13.4b) and triangular (i.e. form 'A-frame' junctions, Fig. 13.4c). Several of these components are clearly artificial.
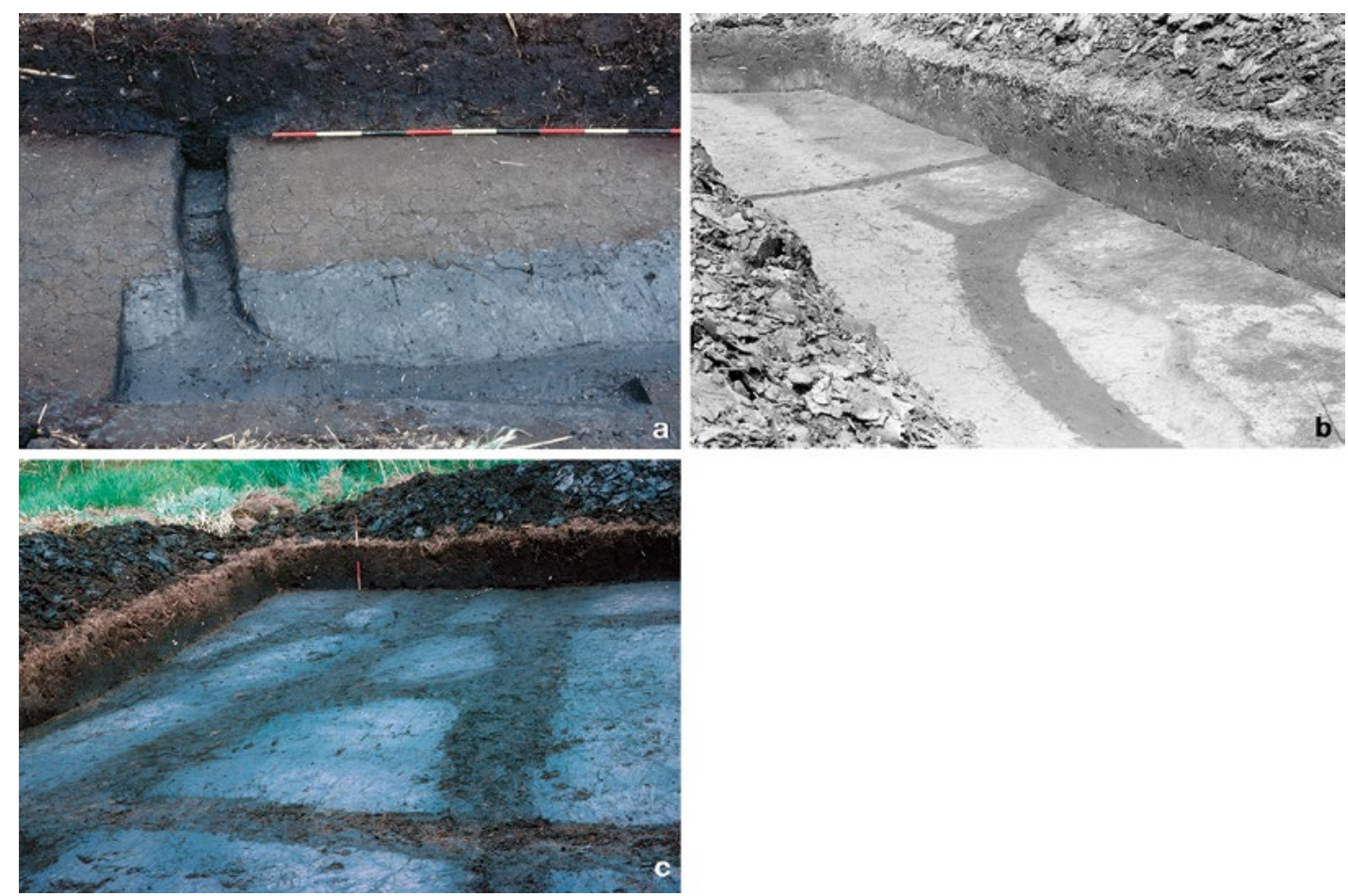

Figure 13.4 Different types of ditch articulation in Phase 3 networks at Kuk.

a) rectilinear, formed by right-angled junctions, like ditch 516 with ditch 513 at the lower right of the 353 complex; b) dendritic, like ditch 290 with ditch 393 at the north end of block A12c; c) triangular, like the small cross ditch in the middle of the picture between ditches 350 and 393, on the line of the undug drain A12e/f. The ranging pole is graduated at $200 \mathrm{~mm}$ intervals.

Sources: Photograph a) Alistair Marshall; photographs b) and c) Klim Gollan, Kuk archive, 1975-76.

Phase 3 ditches are limited to the southern wetland margin at Kuk, with very few occurring in $\mathrm{C}$ and $\mathrm{D}$ blocks. These more northerly areas are presumed to have been too wet to make drainage viable and were left as swampland. Phase 3 subphases at Kuk probably represent relatively continuous but spatially variable drainage and cultivation of the wetland edge, but there is currently insufficient archaeological precision to clarify each period of use for a given locale.

\section{Palaeochannels}

Based on radiocarbon dates and stratigraphic relationships, at least two palaeochannels $(106,107)$ and possibly three more $(102,103,108)$ are associated with Phase 3 ditch networks (Fig. 13.5a-d; Denham 2003a: 219-225). Kui's Baret (channel 102) is probably associated with Phase 3, but could also be of late Phase 2 age, based on the available dating and stratigraphic evidence. The majority of channel 102 was destroyed by the digging of a later channel, 106, on the same alignment. Kum's Baret (channel 103) was potentially open during early Phase 3 as it is broadly contemporaneous with Joseph's Baret (channel 107), which articulates with early Phase 3 ditches. Most Phase 3 palaeochannels are clearly artificial, but the mode of formation of Nema's Baret (channel 108) is uncertain and open to debate (Denham 2003a: 222-224). 
a) channel 107

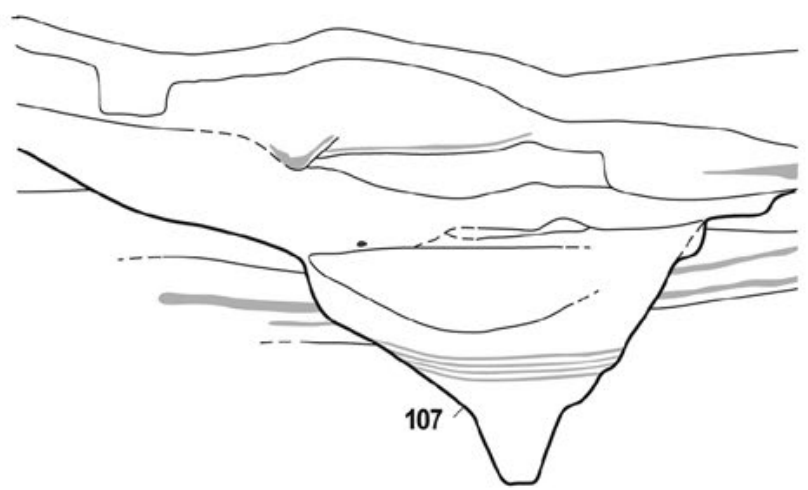

b) channel 103

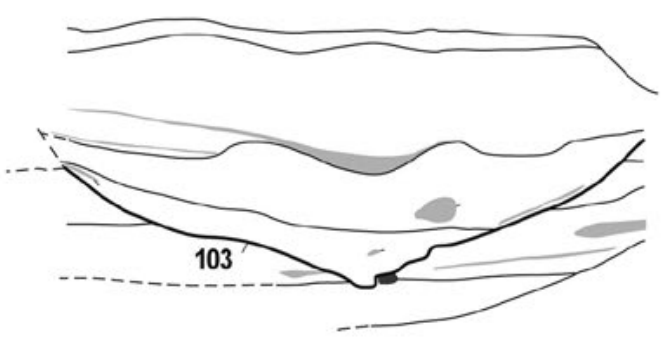

c) channels 101,102 and 106

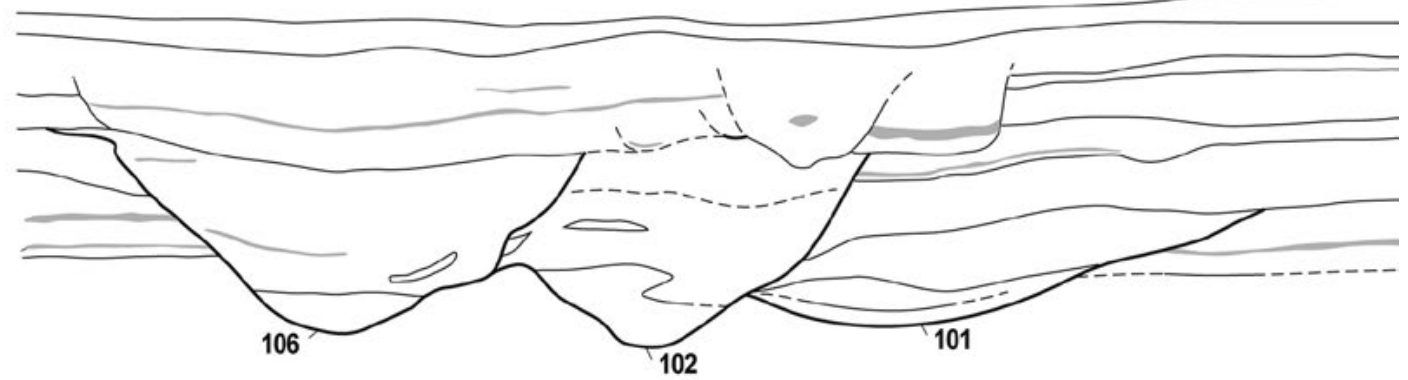

d) channel 108

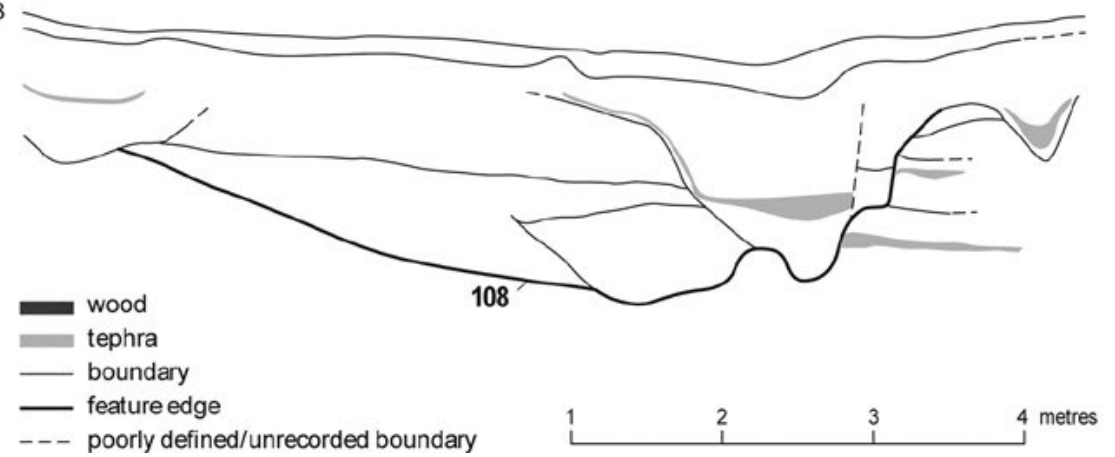

Figure 13.5 Typical cross-sections of palaeochannels of certain and possible Phase 3 age plotted on Figure 13.7.

a) channel 107 (cf. Fig. 13.6); b) possibly channel 103; c) channel 106 and possibly 102); and d) channel 108. Source: Denham, Golson and Hughes (2004: Fig. 5), reproduced with permission. 


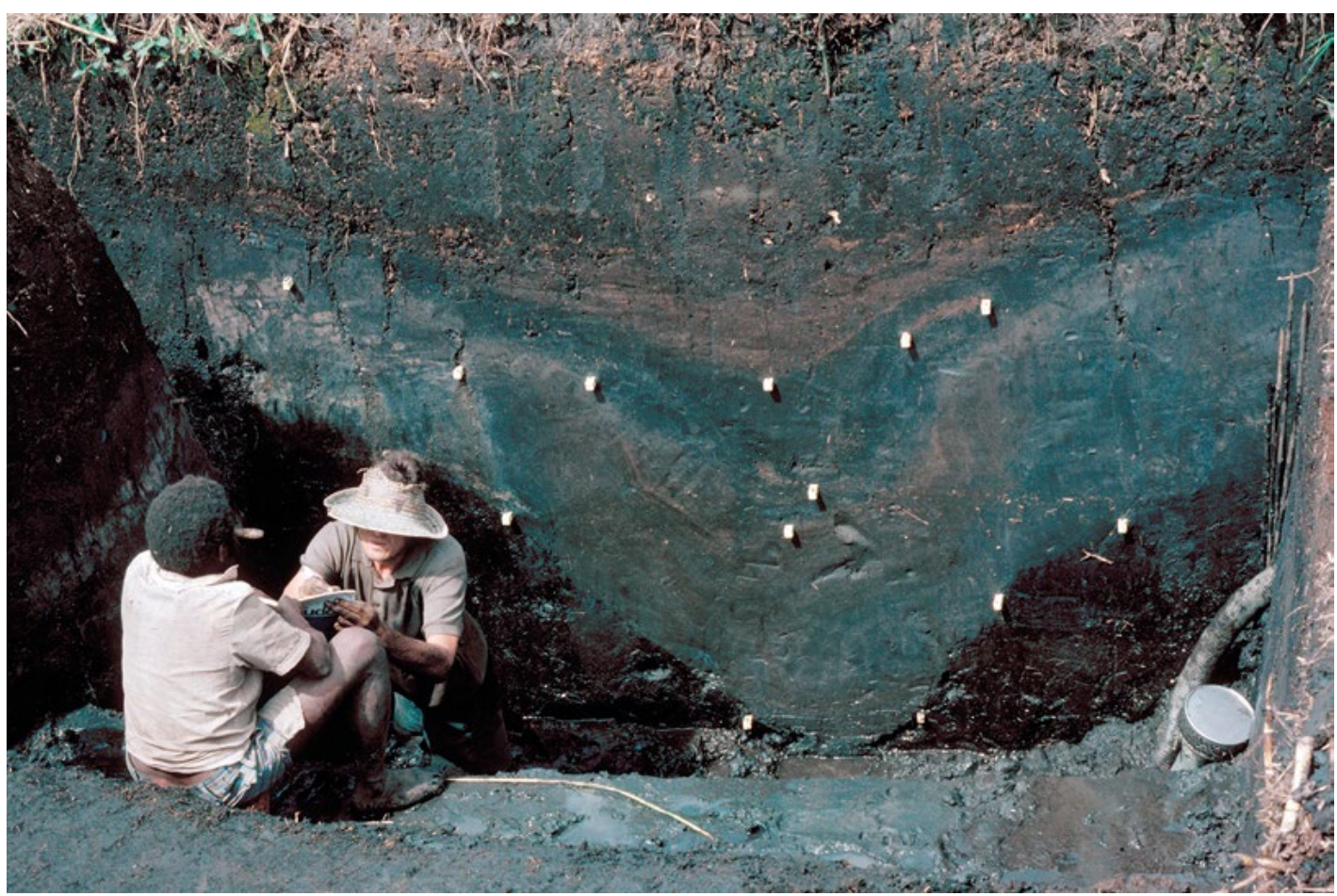

Figure 13.6 Jack Golson recording the profile of channel 107 at the west wall of drain A11e/f towards its north end.

Source: Photograph by Klim Gollan, Kuk archive, 1975.

Channels 102 (where not destroyed by the later digging of channel 106 along the same course), 103, 106 and 107 all have U- to V-shaped cross-sectional morphologies (Figs 13.5a-d and 13.6), which are more angular than those of early Phase 2 . These palaeochannels follow extremely straight courses that are visible on aerial photographs and have been independently reconstructed from plantation drain wall records and excavation trenches (cf. Fig. 13.7). They cut across low rises on the present-day landscape, although, as discussed for earlier palaeochannels, this may be a product of more recent differential shrinkage of the stratigraphy (Denham, Golson and Hughes 2004: 269-274). Additionally, channel 106 was recut along the course of channel 102 for much of its length. Taken together, these characteristics suggest all four palaeochannels were humanly made.

By contrast, the course and cross-sectional morphology of channel 108 are more suggestive to Denham of a natural watercourse. In plan it lacks the straighter reaches of other Phase 3 palaeochannels and follows a meandering course (see Fig. 13.7). In cross-section it is wider and shallower, much like channels 104 and 109 of early Phase 2 (see Fig. 12.4), and exhibits several episodes of within-bank migration, although these might be interpreted as redigging (cf. Fig. 13.5d). The age of channel 108 is uncertain because radiocarbon dates on organic materials within basal fills do not produce a robust sequence and its stratigraphic relationships are unclear.

Excavations showed the direct articulation of two palaeochannels, 106 and 107, with ditch networks (Fig. 13.2a); channel 106 articulates with a late subphase ditch network (350/393) and channel 107 articulates with two early subphase ditches (242 and 340). One of the ditches of the late 350/393 complex was cut along the course of channel 107 after it had filled and been abandoned. No ditches were found to articulate with channel 108 in the limited excavations undertaken. 


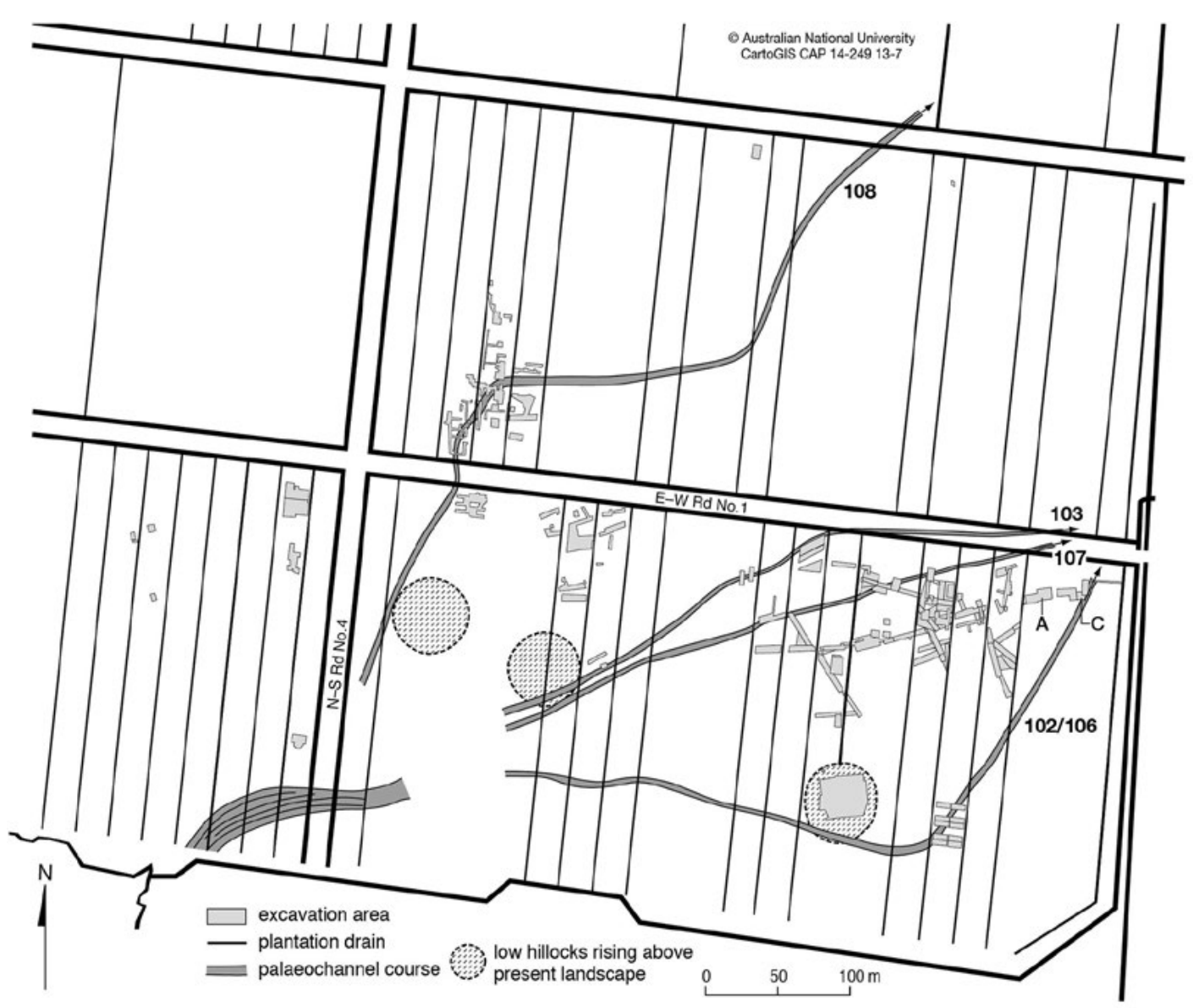

Figure 13.7 Plan showing the course of two certain Phase 3 channels (106 and 107) and three possible channels $(102,103$ and 108) across the SE corner of Kuk Station.

The letters $A$ and $C$, at the eastern end of the plan, just south of E-W Rd 1, mark the findspots of objects discussed in Chapter 20. $A$ is the location of a possible axe and B marks a collection of stones from a cooking pit dug into a Phase 3 ditch.

Source: Denham, Golson and Hughes (2004: Fig. 5), reproduced with permission. Drawing by Jennifer Sheehan, CartoGIS Services, College of Asia and the Pacific, ANU.

In summary, most Phase 3 palaeochannels are clearly artificial and were dug to articulate with ditch networks. The construction of these large-scale drainage features marks a technological innovation from previous practices; they unequivocally represent deliberate and planned attempts to drain the wetland margin for cultivation. Large-scale palaeochannels were dug to divert incident water from the southern catchment and to receive discharge from artificial ditch networks that were dug to lower the watertable on the wetland margin. At present, the age and archaeological associations of channels 102 and 108 are unclear and require further investigation.

\section{Early ditch networks around $4400-4000$ years ago}

A conservative interpretation of radiometric age determinations on a ditch fill (ditch 353, dates OZF239 and OZF240) indicates that early subphase ditch networks date to around 4400-4000 years ago (Denham et al. 2003: Table S1; Denham 2005a: 345). Three early subphase ditch networks are associated with the deposition of a distinctive three-part fill sequence comprising alternating black, grey and black clays (Fig. 13.8). All three early ditch networks exhibit rectilinear alignments with dominant orientations of north-northwest and east-northeast (Fig. 13.2): the 107 complex consists of two ditches that articulate directly with channel 107 (Fig. 13.2a); 
the 353 complex consists of an integrated drainage hierarchy of ditches (Fig. 13.2a); and the 585 complex delimits a possible enclosure (Fig. 13.2b). Each ditch complex is numbered after a major constituent feature.

The 353 and 585 complexes have different network designs, hierarchies and patterns. The 353 complex in block A12b (Fig. 13.2a) has three levels within a drainage hierarchy, each of which is interpreted to have corresponding functions (Denham 2003a: Fig. 6.10):

1. a major water conduit (ditch 353) to a palaeochannel (presumed to be channel 107);

2. two tributaries joining 353 at right angles (ditches 225 and 513); and

3. two plot-dividing ditches joining the tributaries almost at right angles (ditch 516 joining 513 and ditch 519 joining 225).

In contrast, the 585 complex in blocks A10f and A10g (Fig. 13.2b) has no defined drainage hierarchy and ditches of different sizes articulate to define an enclosed area measuring $29 \mathrm{~m}$ by $24 \mathrm{~m}$. This ditched enclosure is the earliest excavated in New Guinea.

\section{Mid to late ditches}

Numerous ditches of uncertain age and association have been put into a mid to late category based on the stratigraphic characteristics of their infilling. The spatial extent of individual ditches, as well as the drainage networks of which they are part, are poorly defined and can only be partially extrapolated. In the southern portion of the B blocks, these limited extrapolations exhibit regular right-angled patterns that can be extended to form rectilinear drainage networks. These ditch networks define rectangular enclosures, similar to that of the early subphase (585 complex of Fig. 13.2b), and are suggestive of field systems.

\section{Late ditch networks predating the age range 2700-2400 years ago}

The age range for this subphase is based on a stratigraphic position predating Baglaga (Y) ash, which is poorly dated between 2650 and 1950 calibrated years BP (Denham et al. 2003: Table S2), and the secondary fill of a Phase 3 ditch that was radiocarbon dated to

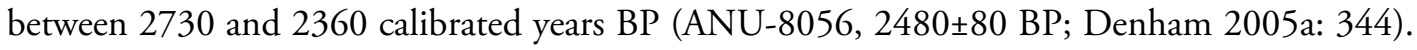
Consequently, 2700-2500 years ago is a conservative estimate for the antiquity of late Phase 3 ditches at Kuk. However, the late subphase, characterised by the 203 and 350/393 complexes (Fig. 13.2a), did not greatly predate the fall of Baglaga $(\mathrm{Y})$ ash. This is illustrated by the presence of the ash low in the fills of late subphase ditches (Figs 13.3c and 13.9). The spatial design of these ditch networks included offset and oblique (dendritic), right-angled (rectilinear) and A-frame (triangular) junctions (Figs 13.2a and 13.4).

The 350/393 complex (Figure 13.2a) articulated with channel 106. One of the ditches of the complex (393) came in from the west-northwest (Fig. 13.10) after having followed the alignment of channel 107 for a short distance, where it was cut into the post-abandonment fills. An association between the 203 complex (Fig. 13.2a) and a palaeochannel was not established. The form of constituent features varied, with the ditches of the 203 complex being narrower, deeper and more angular than those of the 350/393 complex. Differences in form may reflect the amount of time ditches were in use prior to abandonment or reflect different digging styles and techniques.

Continuities between the two complexes are exhibited in similar network designs and reuse of older ditch lines. The 203 complex slightly predates the 350/393 complex, with the latter including recut and modified elements of the former. The continuity of form suggests that groups with a shared cultural tradition constructed both networks. 


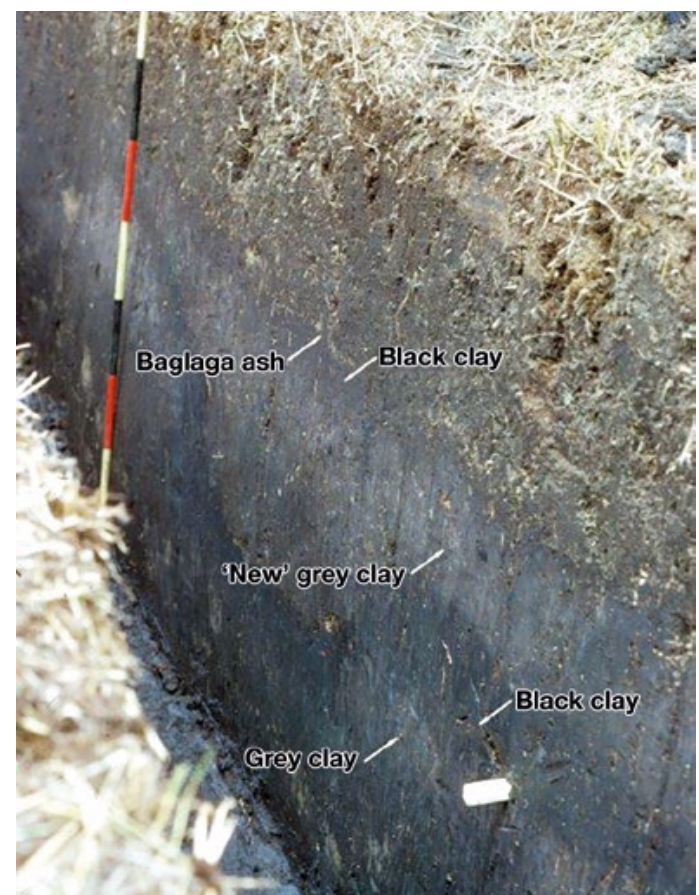

Figure 13.8 A typical early Phase 3 ditch, with steep sides, flat base and characteristic threepart fill sequence.

The fill sequence consists of basal black clay, middle (or 'new') grey clay and upper black clay. Above the fill is a short discontinuous lens of Baglaga $(Y)$ ash. The ranging pole is divided at $200 \mathrm{~mm}$ intervals.

Source: Photograph by Philip Hughes, Kuk archive, 1974.

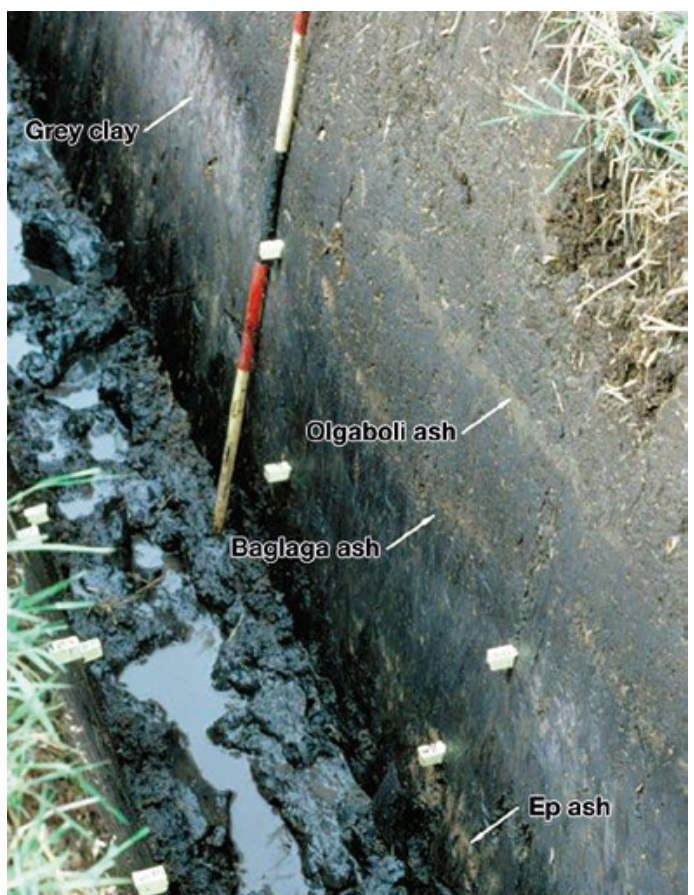

Figure 13.9 A typical late Phase 3 ditch, with steep sides, flat base, a conspicuous dip of Baglaga (Y) ash above a soft black clay fill and an overlying lens of Olgaboli (Q) ash.

The ranging pole is divided at $200 \mathrm{~mm}$ intervals.

Source: Photograph by Philip Hughes, Kuk archive, 1974.

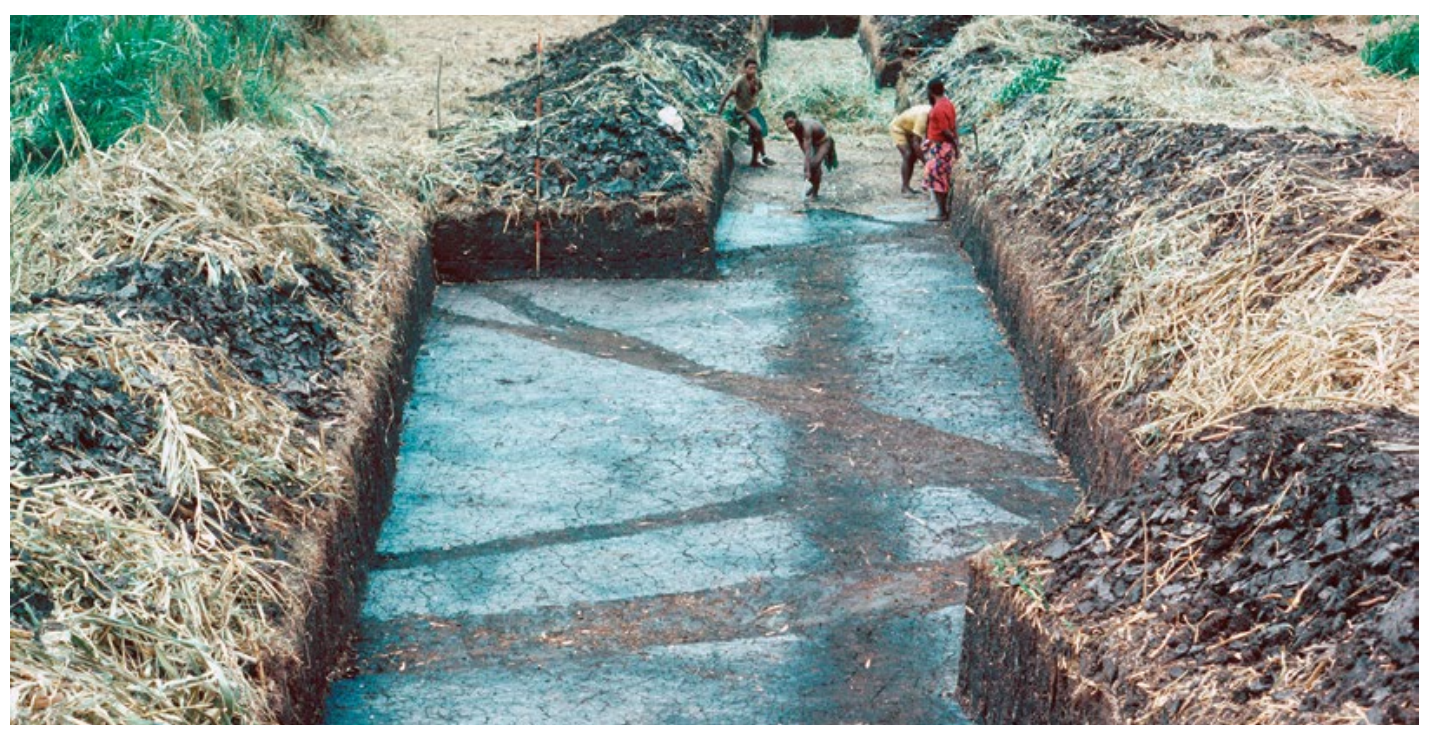

Figure 13.10 Looking WNW in block A12b upstream along the course of ditch 393 of the 350/393 complex of Figure 13.2a.

Ditch 393 is exposed at the surface of grey clay, where there are also faint indications of Phase 2 features. The straight-line ditching across the excavation trench belongs to later phases, mainly Phase 5. For a plan of 393 and the later ditches see Denham (2003a: Fig. 5.21 upper).

Source: Photograph by Klim Gollan, Kuk archive, 1975. 


\section{Landuse}

Only early Phase 3 contexts have been subject to detailed analyses to reconstruct prehistoric environments, because multidisciplinary investigations have focused upon the earliest manifestations of cultivation at Kuk (Denham 2003a; see Chapter 9 here). The environment at that time was similar to, but distinct from that of Phase 2 (Denham, Haberle and Lentfer 2004; Haberle et al. 2012). Grasslands predominated, although there was limited recovery of forest species within the catchment during Phase 3 (Denham, Sniderman et al. 2009).

There were decreased frequencies of Musa section banana phytoliths in samples collected from black clay, i.e. up to 2500 years ago (see Fig. 10.1, Table 10.1 and Textbox 10.2). However, the fills of ditches and palaeochannels associated with early Phase 3 generally exhibited higher Musaceae frequencies, whereas later Phase 3 drainage phases have not been subject to intensive phytolith investigation (Haberle et al. 2012). The contrast between very low Musaceae phytolith frequencies in black clay and higher frequencies in early Phase 3 features is suggestive of an association between bananas and periods of wetland drainage for cultivation.

\section{Regional processes in the upper Wahgi Valley and beyond}

There are sites providing archaeological evidence of wetland drainage of similar age to Kuk Phase 3 in the upper and middle Wahgi Valley, as well as further west in the upper Kaugel Valley and in the Haeapugua Basin near Tari (see Fig. 13.1, Table 13.1). These sites are briefly discussed below, as well as finds from the Minjigina archaeological site at around $1900 \mathrm{~m}$ altitude at the eastern foot of Mt Hagen.

In 1966, Jack Golson and Wal Ambrose joined Ron Lampert and Jocelyn Powell in archaeological and palynological investigations at the Manton site on the floor of the upper Wahgi Valley at Warrawau Tea Estate (Fig. 13.1; see Chapter 12, Figs 12.16-12.17). Excavation recovered a pointed wooden digging stick from the basal fill of a small linear ditch at $115 \mathrm{~cm}$ below ground surface. The report that announced the find of the stick and its date of $2300 \pm 120 \mathrm{BP}$ (Table 13.1 here, ANU-43; Golson et al. 1967; cf. Lampert 1967) interpreted the artefact and ditch, together with undated finds of wooden digging implements, wooden stakes, ditches and axes, to be consistent with contemporary agricultural practices. When the Kuk investigations began some years later, the date of the stick proved to be contemporary with late Phase 3 at Kuk (Golson 1977a: 621).

Table 13.1 Radiocarbon dates for Phase 3 features at other wetland sites in the highlands.

\begin{tabular}{|l|l|l|l|r|r|r|}
\hline ANU \# & Location & Context & Material & Radiocarbon Age (BP) & Calibrated Date (cal. BP) ${ }^{1}$ & $\%$ \\
\hline Minjigina (Powell 1970a: 174$)^{2}$ & & $2310 \pm 90$ & $2710-2630$ & 0.089 \\
0.039 & $2620-2560$ & $2540-2110$ & 0.873 \\
\hline 255 & Cooking pit & fill & Charcoal & & & \\
\hline
\end{tabular}




\begin{tabular}{|l|l|l|l|r|r|r|}
\hline ANU \# & Location & Context & Material & Radiocarbon Age (BP) & Calibrated Date (cal. BP) & $\%$ \\
\hline \multicolumn{7}{|l|}{ Tambul (Golson 1996: 155) }
\end{tabular}

Source: Denham (2005a: Table 5).

Notes:

${ }^{1}$ All calibrations were undertaken to two sigma, Method B, Calib 4.1, IntCal98 atmospheric curve (Stuiver and Reimer 1993). ${ }^{2}$ A date of $2280 \pm 90 \mathrm{BP}$ (ANU-277) obtained on the basal fill of a ditch at Minjigina is not considered to be representative of Phase 3, but has been interpreted as deriving from a Phase 4 feature (Golson 1982: 121; Golson and Steensberg 1985: 376).

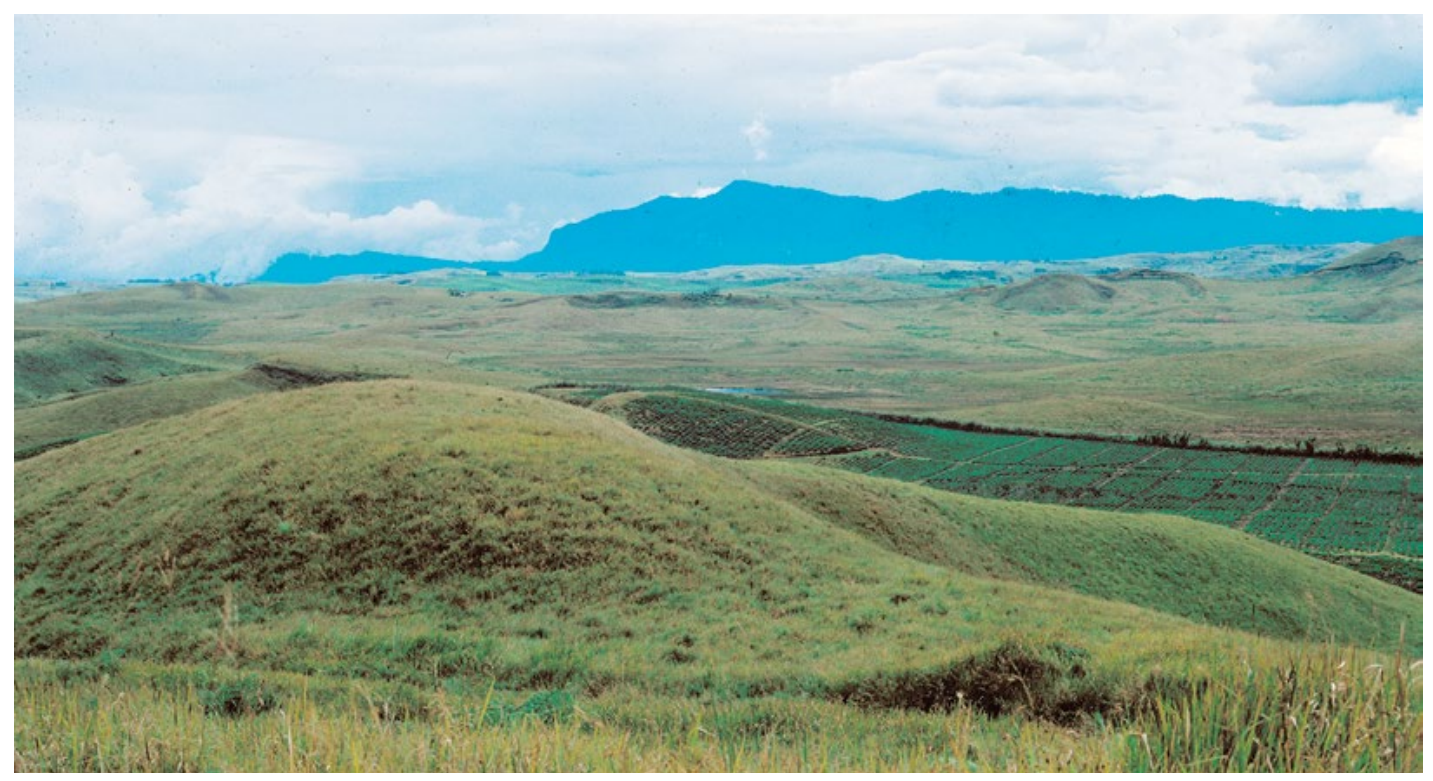

Figure 13.11 Looking slightly WSW over Draepi Swamp and the Minjigina Tea Estate at an early stage of its development, about $2000 \mathrm{~m}$ altitude and some $13 \mathrm{~km}$ NNW of Mount Hagen town.

Plantation drains can be seen beyond the ridge in the right foreground, with a line of vegetation beyond that. It was here that Jocelyn Powell did palynological work in 1967 (Powell 1970a: Chapter 9; 1982: 218-224) and, following her discovery of archaeological material in newly dug drain walls, that Ron Lampert undertook exploratory excavations later that year (Powell 1970a: Appendix 5).

Source: Photograph by Ron Lampert, Kuk archive, 1973.

A small excavation by Ron Lampert in 1967 at Minjigina on Mt Hagen's volcanic apron at the head of the Wahgi Valley (Fig. 13.11), together with recording in plantation drains by Jocelyn Powell and others over a longer period, revealed 'digging sticks, ditches and an associated cooking pit' (Powell 1970a: 172-174; 1970b: 199). Radiocarbon dates obtained on charcoal from the cooking pit (ANU-255) and on the basal fill of a ditch (ANU-277) were comparable to each other and to the dated wooden digging stick from the Manton site at Warrawau (Table 13.1). However, the presence of Olgaboli (Q) tephra dipping into the Minjigina ditch above a digging stick suggested that both the ditch and stick were contemporary with Kuk Phase 4 and not Phase 3 (Golson and Steensberg 1985: 376; see Chapter 14 here). Charcoal from the cooking pit provided a more secure date than the bulk sediment sample from the ditch and suggests that this wetland margin was sufficiently dry to enable cooking in an earth oven during Kuk Phase 3. 
At Kana, in the middle Wahgi Valley (Fig. 13.1), John Muke and Herman Mandui recorded several features of Kuk Phase 3 or Phase 4 age (Muke and Mandui 2003). Of most significance for an inter-site characterisation of Phase 3 are two radiocarbon dates from two different features, one on a sediment sample from a feature fill and another on exocarp fragments of wax gourd (Benincasa hispida; Matthews 2003; Table 13.1 here; cf. Textbox 10.1). While the dates on both samples correspond to Kuk Phase 3, Muke and Mandui (2003: 184) interpret the first of the two features as belonging to Phase 2 because of the claimed presence of Kim (R) tephra above the fill. Irrespective of debates over their precise age, Muke and Mandui report several linear features that are at least of Phase 3 age.

In 1976, Jack Golson and Philip Hughes conducted limited archaeological recording at the Tambul High Altitude Experiment Station (HAES) of the then Department of Agriculture, Stock and Fisheries, at $2240 \mathrm{~m}$ altitude in the upper Kaugel Valley (Fig. 13.1). They investigated the circumstances of an archaeological discovery made earlier in the year by Station personnel digging a new drain (Golson 1996). The discovery was that of a hastate-type spade (Fig. 13.12) lying in the bottom of a prehistoric ditch cut across by the modern drain (Figure 13.13; on hastate spades see Chapter 19, section 'Shorter paddle tools'). Dating between some 4500 and 4000 years ago (Golson 1996: 157), the Tambul spade is the oldest reported wooden digging implement in Papua New Guinea (Table 13.1). Similar types of wooden spade have been documented in use by people in Papua New Guinea in the recent past (Fig. 13.14).

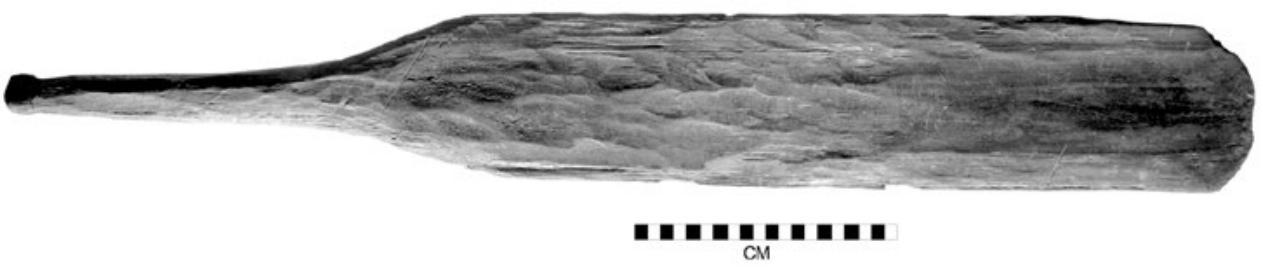

Figure 13.12 The Tambul spade.

Source: Photograph by Bob Cooper and Darren Boyd.

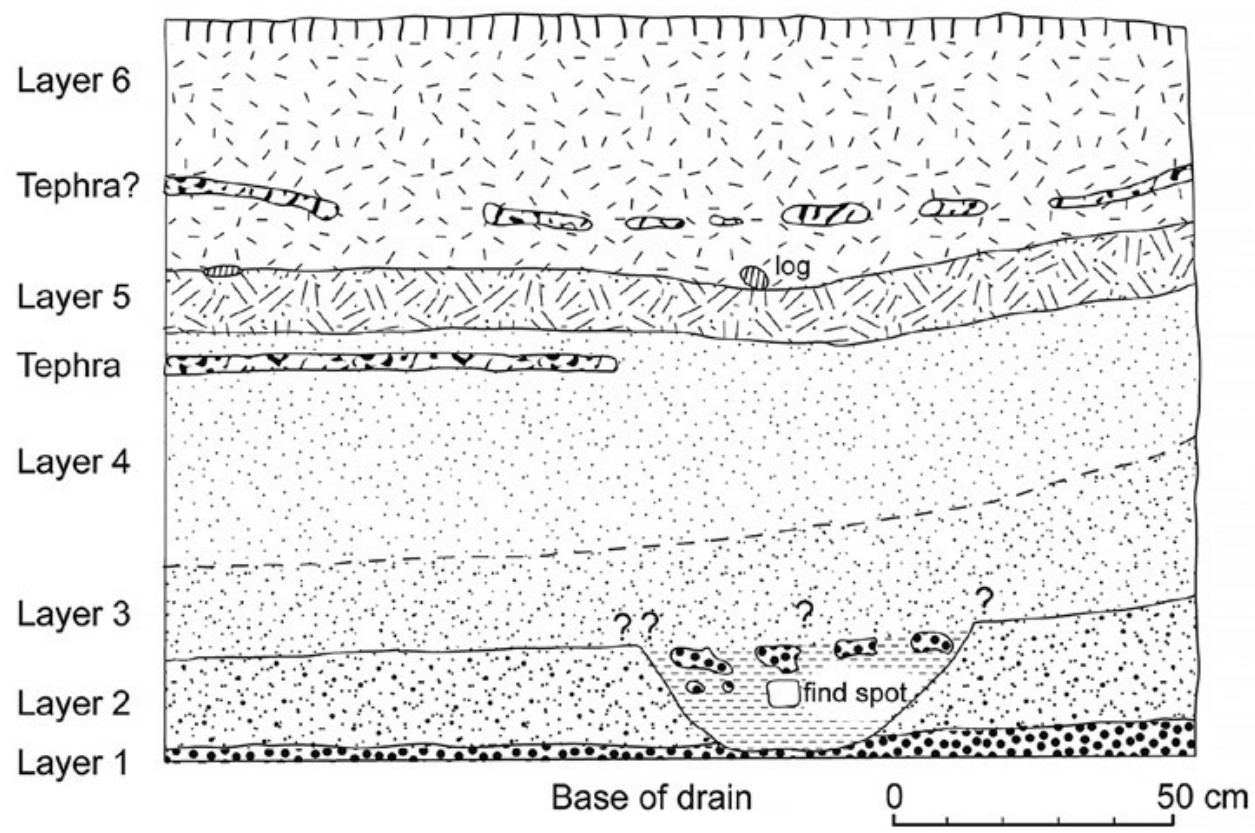

Figure 13.13 West wall section at the findspot of the small wooden paddle-shaped spade in Figure 13.12. Source: Golson (1996: Fig. 3a), reproduced with permission. 


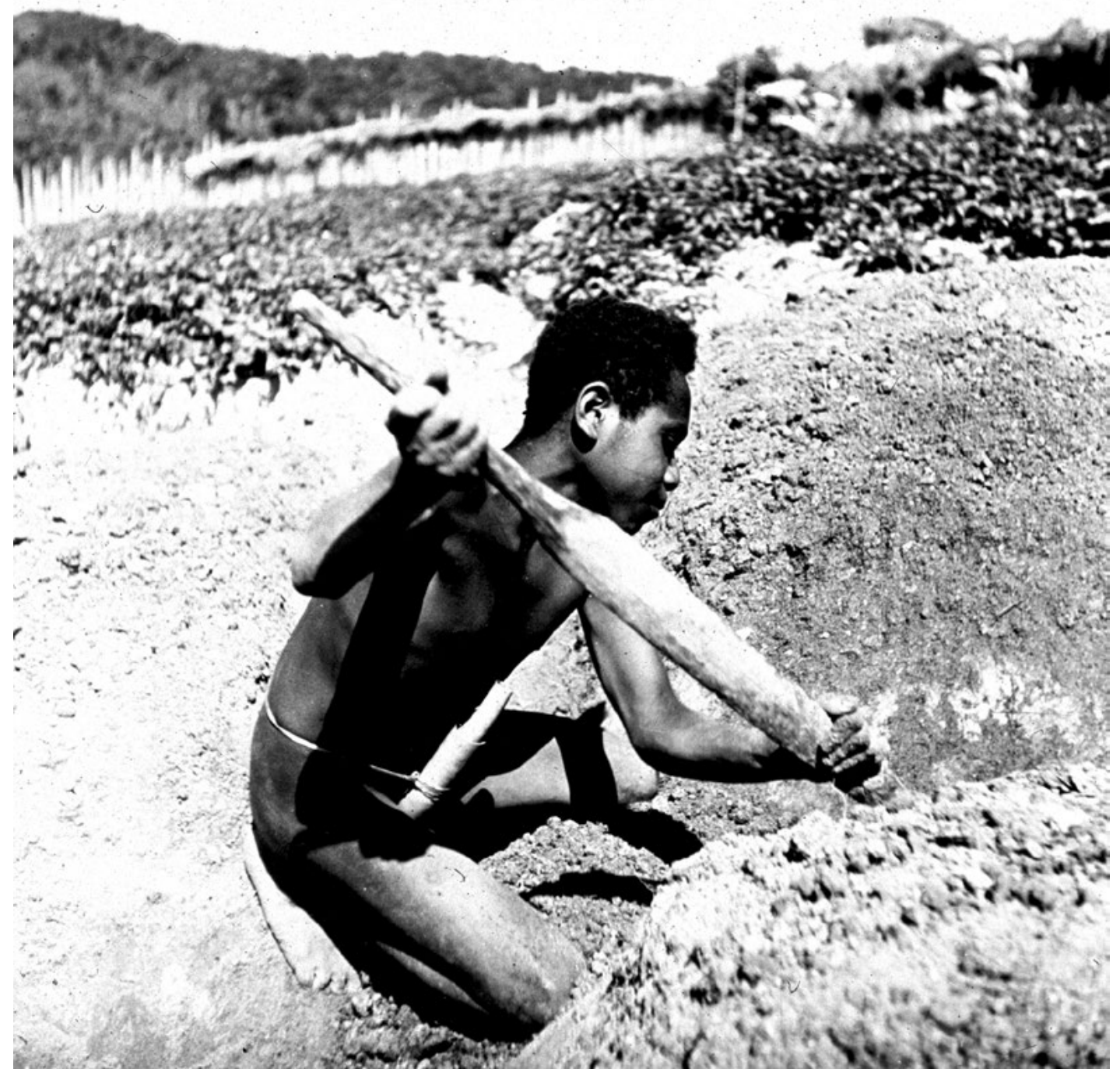

Figure 13.14 A small paddle-shaped spade, comparable to the Tambul spade of Figure 13.12, in use. The spade is being used to trim the walls of a garden ditch by a young Kapauku man at the Paniai (formerly Wissel) Lakes in the highlands of the Indonesian province of Papua.

Source: 1963 photograph by Naomichi Ishige of the National Museum of Ethnology, Osaka, Japan, reproduced with permission.

The evidence from Tambul complements a record of anthropogenic disturbance at Sirunki $(2500 \mathrm{~m})$ in Enga Province (Golson 1996: 164). Walker and Flenley (1979: 339-340) inferred the degradation of primary forest-and its replacement with secondary forest and taxa of disturbance and open land - to be anthropogenic and to roughly date to a period from 4300-3000 years ago. The altitudinal expansion of permanent settlement was interpreted to represent the exploitation of tree crops, hunting and encouragement of useful plants. The evidence from Tambul indicates the altitudinal expansion of agricultural activities into a marginal environment for many of the known cultivars (Bayliss-Smith 1985a, 1988: 155; Golson 1996: 145-146).

Archaeological survey and excavations combined with ethnohistorical research were conducted by Chris Ballard at Haeapugua in the Tari Basin during 1991 and 1992. The earliest evidence of linear ditches in the swamp was found at site LOJ (Fig. 13.15 here; Ballard 1995: C40-46). A radiocarbon date (ANU-7800) obtained on dispersed charcoal collected from the base of 
a linear feature corresponded to late Phase 3 at Kuk and is comparable to dates at Warrawau and Kana (Tables 13.1 and 13.2). Another date obtained on thin and discontinuous patches of dark grey clay at a second site (LOI) corroborated the LOJ date (Ballard 1995: C10:36). Ballard suggests that these finds represent 'the earliest evidence for agriculture in the region' and 'cultural continuity with the current Huli-speaking populations' (1995: 213). He cross-correlates his archaeological findings to a time of increased vegetation disturbance using fire, evidenced in palaeoecological records for the region (Haberle 1998b: 6-7).

Table 13.2 Inter-site chronology for Phase 3.

\begin{tabular}{|l|l|c|c|c|c|}
\hline Date (cal. BP) & Kuk & Tambul & Kana & Warrawau & Haeapugua \\
\hline \multirow{2}{*}{ 2750-2150 } & Late $^{1}$ & & $X$ & $X$ & $X$ \\
\hline & Mid to late & & & \\
\hline c. $4350-3980$ & Early & $X$ & & & \\
\hline
\end{tabular}

Source: Data collated by Denham and Golson.

Notes:

${ }^{1}$ A combined calculation based on ANU-43 (Warrawau), ANU-7800 (Haeapugua) and ANU-9487 (Kana) yields a date range of 2750-2150 cal. BP for this subphase ( $T=0.5,5 \%=6.0,0 x$ Cal v3.3, Bronk Ramsey (1999); reported in Denham (2005a: 347 and Table 5)); this date range incorporates that of 2700-2400 years ago for late Phase 3 at Kuk.

${ }^{2}$ The mid to late correlations between Kuk and Kana are weak and approximate. More than one mid to late ditch network has been documented at Kuk, while only one feature at Kana was dated (ANU-9382).

${ }^{3}$ The dating evidence from an early subphase ditch (353) at Kuk, when interpreted conservatively, yields a date range of 4350-3980 cal. BP (3780 50 BP, 0ZF240; Denham 2005a: Table 4), which overlaps with that of the ditch and spade at Tambul (ANU-2282, see Table 13.1 here).

In summary, ditches have been identified, excavated and dated at several wetland sites in the Wahgi Valley, upper Kaugel Valley and Tari Basin (Fig. 13.1 and Table 13.2). Taken together with the recovery of a spade associated with ditch maintenance at Tambul, these finds indicate prehistoric drainage of the wetland margin. In the absence of suitable domesticated animals, the intervening drained land was almost certainly intended for the cultivation of plants. Cultivation practices were initially considered to comprise swidden cultivation (Walker and Flenley 1979; Bayliss-Smith 1985a), but the Tambul evidence shows they also included more intensive forms of wetland drainage and cultivation, enabling settlement and resulting in forest clearance in relatively high altitude areas by 4000 years ago.

Based on the dates from Haeapugua, Kana and Warrawau, a later expansion of agricultural activities from a more restricted setting, such as Kuk, may have occurred around or before 2700-2400 years ago, the approximate date range for the cessation of Phase 3 ditch digging at Kuk. The archaeological evidence suggests that similar agricultural activities were taking place throughout the Wahgi Valley and in the Tari Basin, as well as, potentially, in other intermontane valleys. People were also using the relatively dry wetland margin at Minjigina at this time. There is insufficient detail in the archaeological records at other sites to determine if wetland cultivation was abandoned at the end of Phase 3, as at Kuk.

Palaeoenvironmental studies in the upper Wahgi Valley and across the highlands reflect the widespread clearance of forest using fire by 4000 years ago. Although forest clearance occurred in several intermontane valleys, the intensity and duration of disturbance varied between sites. These periods of forest disturbance are interpreted as representing clearance for agriculture. 
Plan of Tephra Surface

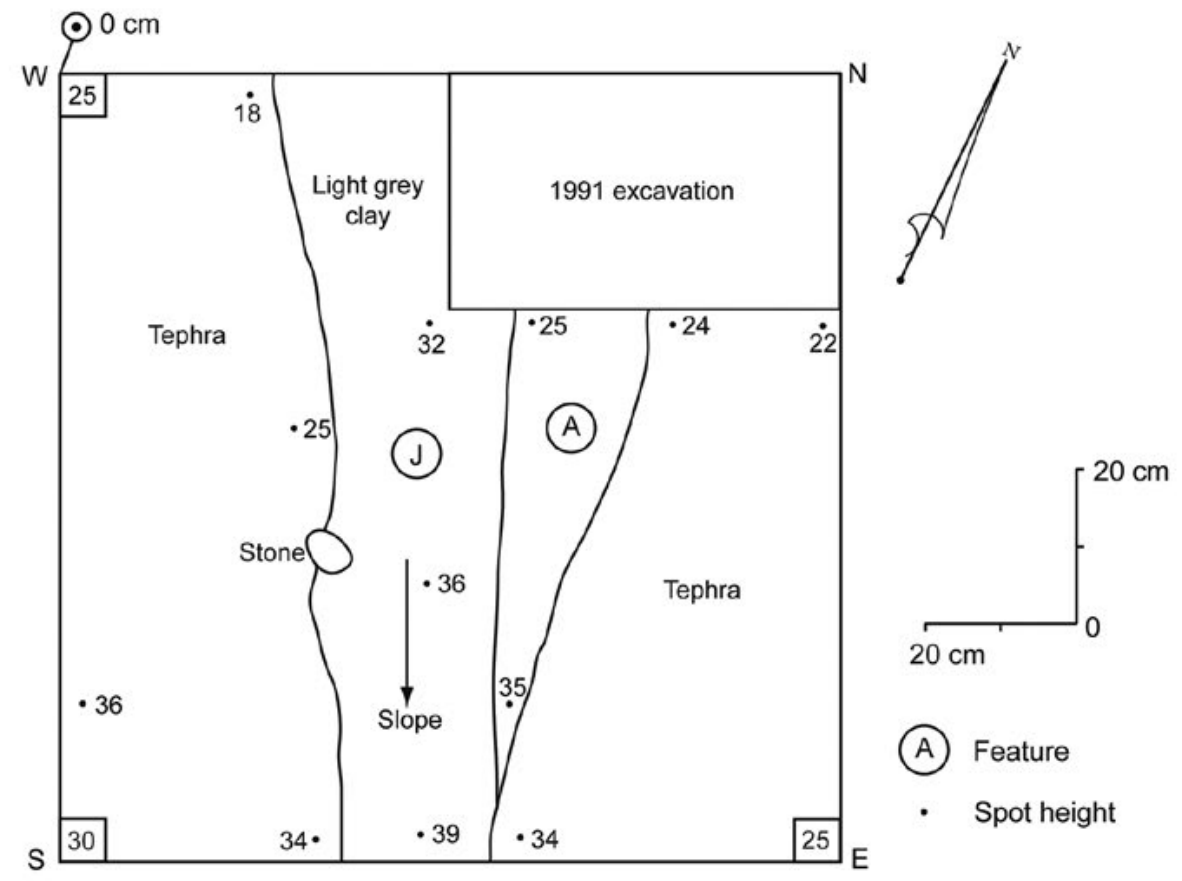

\section{Section}
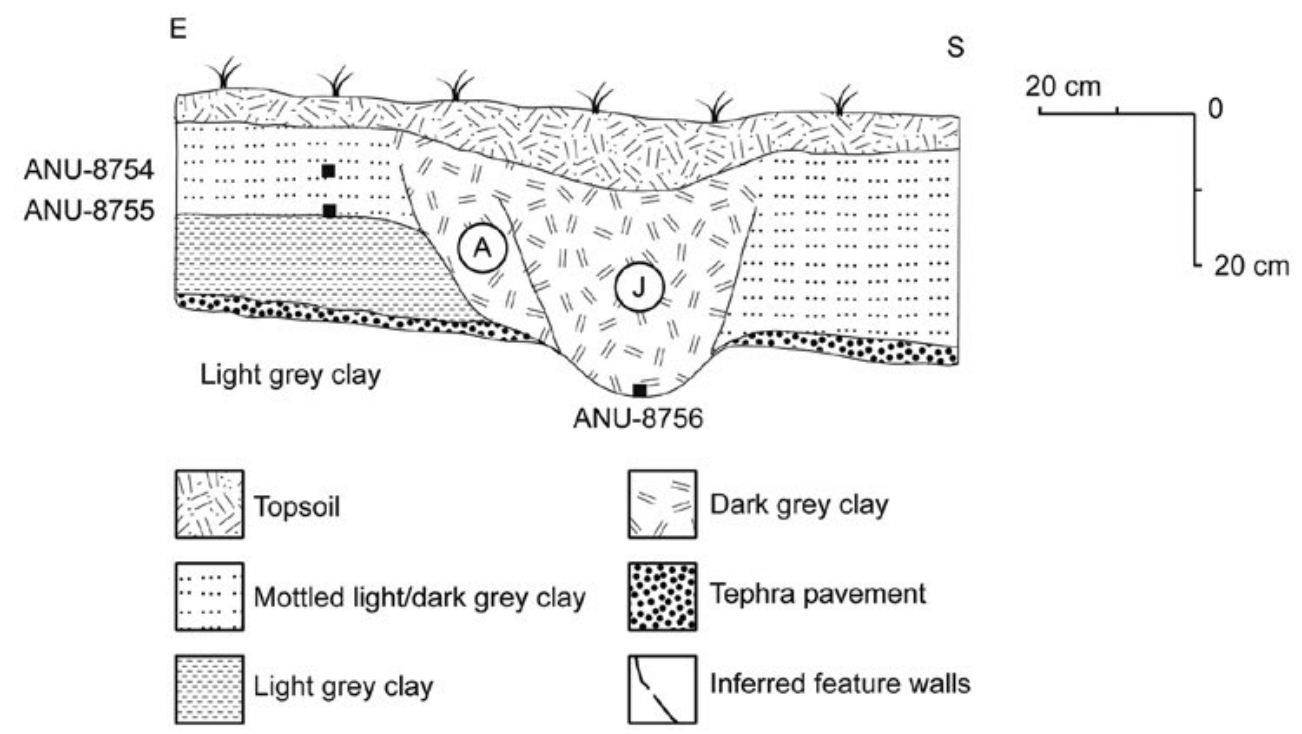

Figure 13.15 Top, base plan; and bottom, cross-section of the 1992 extension of 1991 excavations at site L0), Haeapugua Swamp, Tari Basin, Southern Highlands Province.

Source: Ballard (1995: Fig. L0J/4), reproduced with permission. 
As with contemporary agricultural practices in the highlands of New Guinea, people in the past would have utilised a variety of environments for gardening, hunting and gathering. Archaeological excavations and palaeoecological studies indicate that drainage and cultivation of the wetlands occurred in concert with gardening on adjacent valley slopes. People cultivated plots in different locations for several possible ecological and social reasons:

- to enable the cultivation of plants with different edaphic requirements, e.g. Colocasia taro, yams (Dioscorea spp.), Musa bananas and sugarcane (Saccharum sp.);

- to limit the effects of drought and other catastrophic events, which usually have less impact in wetlands;

- to maintain an admixture of short-cultivation and long-fallow (dryland), with long-cultivation and short-fallow (wetland) plots;

- to spread risk in the event of warfare and subsequent destruction of, or limited access to, gardens; and

- to maintain tenure and rights over fragmented plots inherited within group territories.

If ecological and social issues are considered together, ditches had functional and cultural values. Ditches enabled wetlands to be drained and cultivated, while simultaneously being boundaries and markers of individual and group tenure of the land.

\section{The emergence of ditches in highland New Guinea}

The straighter form of Phase 3 ditches is a break with earlier, more amorphous and curvilinear forms of Phases 1 and 2. This relatively sudden emergence of straight ditches from more curvilinear forms of late Phase 2 is not fully understood (Denham 2005a). There appears to be some continuity between late Phase 2 and early Phase 3 (see Chapter 12), such as the curvilinear feature and two linear features of late Phase 2, which may indicate experimentation with the digging of linear ditch-like features. In addition, there is evidence that channel 107 was dug in late Phase 2 and was maintained and still in use during early Phase 3. These finds point towards a swift on-the-spot transformation of late Phase 2 practices into the digging of drainage ditches during early Phase 3 .

The emergence of rectilinear field forms and associated tools in the highlands occurred independently of outside influences. The early subphase ditch complexes at Kuk and the finds at Tambul predate the appearance of Lapita pottery in the Bismarck Archipelago at 3470-3250 cal. BP and its subsequent dispersal to Remote Oceania from 3250-3100 cal. BP (Denham, Bronk Ramsey and Specht 2012; cf. Spriggs 2001). The absence of comparable finds of similar antiquity in Indo-Malaysia, despite limited archaeological investigations, support the interpretation that the construction of ditches and ditch networks in highland New Guinea is likely to have been an indigenous innovation.

The social distinction between wetland and dryland agricultural practices during Phase 3 is uncertain. In part, Phase 3 ditches at Kuk were necessary to enable drainage of increasingly wet land for cultivation. Their innovation could also have been driven by increasing social needs to demarcate and bound plots of land, such as increasing competition or territoriality within and between social groups, or to minimise risk and maintain production with the advent of increased climatic variability associated with the intensification of El Niño-Southern Oscillation (ENSO; Moy et al. 2002). Once created, wetland plots would have maintained fertility for longer and, consequently, would have been replanted for several years before being left abandoned to fallow. In contrast, plots on dryland slopes would have been cleared from grassland or remnant stands 
of disturbed forest. These dryland plots are likely to have been used for a shorter time, perhaps only a few years, before abandonment due to decreasing soil fertility and crop yields. Furthermore, dryland plots would have been more susceptible to drought.

The transition between Phases 3 and 4 at Kuk is much clearer than that between Phases 2 and 3. First, the patterns of ditch networks differ; those of Phase 3 are variously designed with rectilinear, dendritic and triangular components, whereas those of Phase 4 are organised into more systematic grids (compare Fig. 13.4a-c here to Fig. 14.12). Second, the cross-sectional morphologies of ditches differ: Phase 3 ditches, though variable in form (Fig. 13.3a-c), often have a combination of flat to slightly concave base and steep sides that contrasts with the characteristic slot-like appearance of Phase 4 ditches (see Fig. 14.8). Third, there is a period of some hundreds of years between Phase 3, the later stage of which has been dated to 2700-2500 years ago, and Phase 4, which is thought to have begun around 2000 years ago.

The reasons for the abandonment of wetland cultivation at Kuk, marked by the end of Phase 3, are unknown, but many can be hypothesised. A hydrological cause may include higher watertables along the wetland edge that made continued drainage impractical. Agronomically, the introduction of new crops and techniques of cultivation may have increased or prolonged fertility of horticultural practices on dryland slopes, thereby making wetland cultivation less important (Golson 1977a: 621-623). Social processes leading to wetland abandonment should not be overlooked (see Golson and Gardner 1990). Territorial disputes, warfare and subsequent group displacement could have led to the abandonment of ditch networks, followed by flooding of the wetland; the area could have been recolonised by people who did not know, or did not want to know, how to drain wetlands for cultivation. Although we may never know the precise reason for the abandonment of Phase 3 ditch networks at Kuk, the wetland margin was left uncultivated for some hundreds of years. 
This text is taken from Ten Thousand Years of Cultivation at Kuk Swamp in the Highlands of Papua New Guinea, edited by Jack Golson, Tim Denham, Philip Hughes, Pamela Swadling and John Muke, published 2017 by ANU Press, The Australian National University, Canberra, Australia. 